\title{
Comparative Study between Potassium Fertilizer Sources in The Presence of Boron on Sugar Beet Yield and Juice Quality
}

\author{
Knany, R.E. ${ }^{1}$, A.S.M. El-Saady ${ }^{1}$; R.H. Atia ${ }^{1}$ and N.M. Awad ${ }^{2}$
}

\begin{abstract}
The objective of the present study was to investigate the effect of potassium rock (from the Eastern Desert of Egypt) and K-spraying as alternative potassium sources for the common potassium fertilizer in the presence of boron on sugar beet yield and juice quality. Two field experiments were carried out at Sakha Agricultural Research Station Farm during two winter seasons of $2007 / 2008$ and $2008 / 2009$. Split plot design was used with four replicates. The main plots assigned with two boron treatments: (1) without boron fertilization, and (2) spraying with boron solution two times $(2.4 \mathrm{~kg}$ boric acid $\left.\mathrm{ha}^{-1}\right)$. The sub-plots were assigned with six potassium treatments: (1) without potassium fertilization, (2) application of $115 \mathrm{~kg} \mathrm{~K}_{2} \mathrm{O} \mathrm{ha}^{-1}$ as potassium sulphate $48 \%$, (3) application of $57 \mathrm{~kg} \mathrm{~K}_{2} \mathrm{O} \mathrm{ha}^{-1}$ as potassium sulphate, (4) application of $115 \mathrm{~kg} \mathrm{~K}_{2} \mathrm{O} \mathrm{ha}^{-1}$ as K-rock $\left(7.5 \% \mathrm{~K}_{2} \mathrm{O}\right)$, (5) application of $57 \mathrm{~kg} \mathrm{~K}_{2} \mathrm{O} \mathrm{ha} \mathrm{ha}^{-1}$ as K-rock and (6) spraying with potassium $40 \% \mathrm{~K}_{2} \mathrm{O}\left(4.8 \mathrm{Lha}^{-1}\right)$. The obtained results can be summarized as:
\end{abstract}

Boron fertilization led to increase root yield by 15.6 and $13.9 \%$ in the first and second season, respectively and increased top yield by 33.6 and $38.1 \%$, increased white sugar by 16.2 and $15.2 \%$, increased sodium\%, potassium \%, quality $\%$ in the root, nitrogen $\%$ and $K \%$ in the leaves. The response to boron was less under K-rock source. It also increased sugar beet root and top yields. The highest root and white sugar yields were obtained with the K-rock. K-spraying had the high top yield and root and sugar yields under boron fertilization.

Potassium fertilization increased $\mathrm{N}, \mathrm{P}$ and $\mathrm{K} \%$ in the leaves, $N$ and $K$ in the roots and decreased available $N$ in the soil after harvesting.

The obtained results showed that K-rock was the best source of potassium are present in Egypt. K-spraying in the suitable stage (critical periods) is a good helpful tool in correcting K-insufficiency.

\section{INTRODUCTION}

Sugar beet is becoming an important crop in Egypt as a source of sugar because it grows well in the new reclaimed soils, mature in short period, less requirement of water and fertilizers compared to sugar cane and contain high sugar. Moreover, sugar beet occupies an outstanding position among the world important crops, where it provides about $40 \%$ of the world's sugar production (Abd El-Hadi et al., 2002). Fertilization is the second limiting factor of sugar beet productivity after the variety. The proper fertilization program under the Egyptian conditions needed $\mathrm{N}, \mathrm{P}$ and $\mathrm{K}$ fertilizers. Addition of combined NPK chemical fertilizers produced significantly high root and top yields of sugar beet (Lielah and Taha, 1992 and Abu El-Fotoh et al., 2000). Potassium plays a vital role in photosynthesis carbohydrate transport, protein formation, control of ionic balance, regulation of plant stomata and water use and activation of plant enzymes. The highest values of sugar beet root and top yields, sucrose \%, root/shoot ratio, purity $\%$ and white sugar were obtained with potassium fertilization (Ismail et al., 2002; Osman, 2005; and Zein et al., 2005). The most common potassium fertilizer applied in Egypt is potassium sulphate $\left(48 \% \mathrm{~K}_{2} \mathrm{O}\right)$. It is completely water soluble and has a high salt index. Therefore, some of the potassium fertilizer may lost through the surface drainage and/or the deep percolation, in addition to the potassium sulphate fertilizer is rather expensive (one unit $\mathrm{K}=$ three folds of one unit-N) and become a burden on the agriculture production in Egypt. The extra and losses of chemical fertilizers are not only a waste of the farmer's money, but also an extra load on the environment. For these considerations there are two ways may be useful. The first is to use potassium spraying. In this respect, application of potassium as foliar sprays was found to be a helpful tool in correcting K-insufficiency, especially in the critical periods (El-Fouly and El-Sayed, 1997, Eid et al., 1997 and Knany et al., 2005). The other way is to use potassium bearing minerals and rocks which recognized in many areas in the Eastern Desert. In this respect Shehata (2006) studied the chemical and mineral constitutes in the Eastern Desert of Egypt. He reported that the soluble and exchangeable forms of potassium are quite sufficient for plant growth. The total K-content about $6.96-8.6 \% \quad \mathrm{~K}_{2} \mathrm{O}$. The recommended dose can substitute partly or completely the potassium sulphate which is rather expensive and easily soluble and can be lost through drainage.

Boron is micronutrient required for sugar beet proper development and differentiation of tissues. Boron increase the stability of plant cells, facilitates the transport of carbohydrates through cell membranes. If B-deficiency occurs, the assimilation products accumulate in the leaves and the young growing points are lack sugar, thus maximum production of starch and

${ }^{1}$ Soils, Water and Environment Res. Ins. Agric. Res. Center-Egypt

${ }^{2}$ Sugar Crops Dep. Field Crops Ins. Agric. Res. Center- Egypt

Received November 11, 2009, Accepted December 10, 2009. 
sugar is restricted if crops are inadequately supplied with B. Boron significantly increased sugar beet sucrose $\%$, root and top yields, sugar yield, root/top ratio and purity \% (Saif, Laila, 2000; Osman et al., 2003; Nafei, 2004; Osman et al., 2004 and El-Geddawy et al., 2007). Addition of boron to sugar beet plants increased the concentration and uptake of N, P, K and B in sugar beet tops.

The objective of the present study was to investigate the performance of spraying potassium or using sedimentary rocks containing potassium in presence of boron to substitute the expensive and easily soluble potassium sulphat.

\section{MATERIALS AND METHODS}

Two field experiments were carried out at Sakha Agricultural Research Station farm, Kafr El-Sheikh Governorate Egypt, during two successive winter seasons of 2007/2008 and 2008/2009 on sugar beet crop (Beta vulgaris) to compare between potassium sulphate, sedimentary rocks containing- $\mathrm{K}$, and spraying with potassium in presence and absence of boron on sugar beet yield and quality. Split plot design was used with four replicates. The main plots were assigned with two boron treatments: (1) spraying water without boron and (2) spraying with solution containing $212 \mathrm{ppm} \mathrm{B}$ at the rate of $960 \mathrm{~L} \mathrm{ha}^{-1}$, twice, the first after 45 days from sowing and the second after 90 days from sowing as boric acid $17 \% \mathrm{~B}$ (equal $2.4 \mathrm{~kg}$ boric acid ha ${ }^{-1}$ ). The sub-plots were allotted with six potassium treatments of (1) without potassium application, (2) application of 57

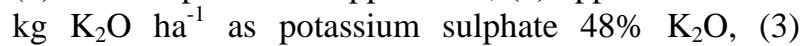
application of $115 \mathrm{~kg} \mathrm{~K}_{2} \mathrm{O} \mathrm{ha} \mathrm{ha}^{-1}$ as potassium sulphate, (4) application of $57 \mathrm{~kg} \mathrm{~K}_{2} \mathrm{O} \mathrm{ha}{ }^{-1}$ as potassium rock $7.5 \% \quad \mathrm{~K}_{2} \mathrm{O}$, (5) application of $115 \mathrm{~kg} \quad \mathrm{~K}_{2} \mathrm{O} \quad \mathrm{ha}^{-1}$ as potassium rock and (6) spraying with solution containing $0.1 \% \mathrm{~K}_{2} \mathrm{O}$ at the rate of $960 \mathrm{~L} \mathrm{ha}^{-1}$ at two times of 45 and 90 days from sowing (equal $4.8 \mathrm{~L} \mathrm{ha}^{-1}$.) potassium $40 \% \quad \mathrm{~K}_{2} \mathrm{O}$ (prepared by solubilizing the potassium in solution containing fulvic acid prepared by Soil Fertility and Plant Nutrition Department, Soils, Water and Environment Institute, Sakha Station). Composite surface $(0-30 \mathrm{~cm})$ soil samples from the field experiments were collected before sowing for physical and chemical analysis according to Jackson (1958) and Black et al. (1965). Data of the main physical and chemical characteristics of soils are given in (Table 1). The sub plot area was $15 \mathrm{~m}^{2}$ [ $3 \mathrm{~m}$ in width (5 ridges $\mathrm{x} 60$ $\mathrm{cm})$ and $5 \mathrm{~m}$ in length]. Sugar beet seeds were planted on ridges $60 \mathrm{~cm}$ width and $25 \mathrm{~cm}$ between hills. In the suitable stage seeding were thinned to one plant. Nitrogen at the rate of $168 \mathrm{~kg} \mathrm{~N} \mathrm{ha}^{-1}$ was added on two equal doses as urea $(46 \% \mathrm{~N})$ with the second and third irrigation. Phosphorus was added at the rate of $72 \mathrm{~kg}$ $\mathrm{P}_{2} \mathrm{O}_{5}$ ha $^{-1}$ as single superphosphate $\left(15.5 \% \mathrm{P}_{2} \mathrm{O}_{5}\right)$ before sowing. The common agricultural practices were done as recommended. At harvest root and top yields were recorded. Randomly root sample from each sub plot was collected and analysed for sucrose, Na, K, $\alpha$ amino nitrogen and quality \% at the Sugar Factory Laboratory, El-Hamol district, Kafr El-Sheikh Governorate. After crop harvesting, available soil $\mathrm{N}$ was extracted by $2 \mathrm{~N}$ $\mathrm{KCl}$ and nitrogen was determined using microkejeldahl method. Available-K was extracted by ammonium acetate $(1 \mathrm{~N})$ and determined by flame photometer according to Jackson (1958). The obtained data were statistically analysed according to Gomiz and Gomiz (1984). Available phosphorus in the soil was extracted by $0.5 \mathrm{~N} \mathrm{NaHCO}_{3}$ and determined colorimetrically. The leave samples were oven dried at $70^{\circ} \mathrm{C}$ for 48 hours, finely ground, wet digested using sulphoric perchloric acids mixture, and $\mathrm{N}, \mathrm{P}$ and $\mathrm{K}$ were determined in the digested solution, according to Jackson (1958).

\section{RERSULTS AND DISCUSSION}

Table 2 showed that boron treatments increased significantly sugar beet root yield in both seasons. The values of $\Delta \%$ increase, due to boron spraying, ranged between 21.7\%; under no potassium fertilization treatment, to $4.2 \%$ under $115 \mathrm{~kg} \mathrm{~K}_{2} \mathrm{O} \mathrm{ha}{ }^{-1}$ from the potassium rock at the average of $15.6 \%$ in the first season. In the second season, the $\Delta \%$ increase due to boron fertilization ranged between $21 \%$ under no potassium fertilization to $4.8 \%$ under $115 \mathrm{~kg} \mathrm{~K}_{2} \mathrm{O} \mathrm{ha}{ }^{-1}$ as potassium rock. This indicates that the experiments soils showed high significantly response to boron spraying,

Table 1. The main physical and chemical properties of the experimental soils

\begin{tabular}{|c|c|c|c|c|c|c|c|c|c|c|c|}
\hline \multirow{2}{*}{ Season } & \multicolumn{3}{|c|}{ Mechanical analysis } & \multirow{2}{*}{ Texture } & \multirow{2}{*}{$\mathbf{p} \mathbf{H}^{*}$} & \multirow{2}{*}{$\begin{array}{c}E C e^{* *} \\
d \mathrm{dSm}^{-1}\end{array}$} & \multirow{2}{*}{$\begin{array}{c}\text { Organic } \\
\text { matter \% }\end{array}$} & \multicolumn{4}{|c|}{ Available nutrients $\mathrm{mg} \mathrm{kg}^{-1}$} \\
\hline & Sand $\%$ & Silt \% & Clay $\%$ & & & & & $\mathbf{N}$ & $\mathbf{P}$ & $\mathbf{K}$ & B**** \\
\hline $2007 / 2008$ & 20.60 & 21.70 & 57.70 & Cla & 7.7 & 2.5 & 1.6 & 25.8 & 19.5 & 440.9 & 1.4 \\
\hline $2008 / 2009$ & 20.40 & 21.60 & 58.00 & Clayey & 7.9 & 2.5 & 1.7 & 27.3 & 22.0 & 432.8 & 1.1 \\
\hline
\end{tabular}

*Soil $\mathrm{pH}$ in 1: 2.5 soil: water suspension

**ECe in the soil paste extract.

***Hot water extraction

Table 2.Sugar beet root yield (ton $\mathrm{ha}^{-1}$ ) as affected by boron and potassium fertilization 


\begin{tabular}{|c|c|c|c|c|c|c|c|c|}
\hline \multirow{2}{*}{ Treat. } & \multicolumn{2}{|c|}{$1^{\text {st }}$ season } & \multirow[b]{2}{*}{ Diff. } & \multirow[b]{2}{*}{$\Delta \%$} & \multicolumn{2}{|c|}{$2^{\text {nd }}$ season } & \multirow[b]{2}{*}{ Diff. } & \multirow[b]{2}{*}{$\Delta \%$} \\
\hline & $\begin{array}{c}\text { Without } \\
\text { boron }\end{array}$ & $\begin{array}{c}\text { With } \\
\text { boron }\end{array}$ & & & $\begin{array}{c}\text { Without } \\
\text { boron }\end{array}$ & $\begin{array}{l}\text { With } \\
\text { boron }\end{array}$ & & \\
\hline Without & $44.21 \mathrm{c}$ & $56.50 \mathrm{c}$ & 12.29 & 21.7 & $45.48 \mathrm{c}$ & $57.60 \mathrm{c}$ & 12.12 & 21.0 \\
\hline $115 \mathrm{~K}_{2} \mathrm{SO}_{4}$ & $54.31 \mathrm{ab}$ & $61.78 \mathrm{ab}$ & 7.46 & 12.1 & $58.22 \mathrm{a}$ & $64.61 \mathrm{a}$ & 6.38 & 9.8 \\
\hline $57 \mathrm{~K}_{2} \mathrm{SO}_{4}$ & $49.90 \mathrm{~b}$ & $63.2 \mathrm{ab}$ & 13.34 & 21.1 & $52.68 \mathrm{~b}$ & $63.60 \mathrm{ab}$ & 10.92 & 17.1 \\
\hline 115 K-rock & $58.25 \mathrm{a}$ & $60.82 \mathrm{bc}$ & 2.57 & 4.2 & $57.58 \mathrm{a}$ & $60.50 \mathrm{bc}$ & 2.93 & 4.8 \\
\hline 57 K-rock & $51.36 \mathrm{~b}$ & $59.37 \mathrm{bc}$ & 8.02 & 13.5 & $51.31 \mathrm{~b}$ & $58.80 \mathrm{c}$ & 7.49 & 12.7 \\
\hline K-spray & $52.58 \mathrm{~b}$ & $66.60 \mathrm{a}$ & 14.02 & 21.0 & $51.24 \mathrm{~b}$ & $62.93 \mathrm{ab}$ & 11.69 & 18.5 \\
\hline \multirow[t]{5}{*}{ Means } & 51.77 & 61.39 & 9.62 & 15.6 & 52.75 & 61.34 & 8.59 & 13.9 \\
\hline & \multicolumn{2}{|l|}{ F-test } & \multicolumn{2}{|c|}{$1^{\text {st }}$ season } & \multicolumn{4}{|c|}{$2^{\text {nd }}$ season } \\
\hline & Boron & & \multicolumn{2}{|c|}{$* *$} & \multicolumn{4}{|c|}{$* *$} \\
\hline & \multicolumn{2}{|l|}{ K-treat. } & \multicolumn{2}{|c|}{$* *$} & \multicolumn{4}{|c|}{$* *$} \\
\hline & \multicolumn{2}{|l|}{ B x K } & \multicolumn{2}{|r|}{ * } & \multicolumn{4}{|c|}{ * } \\
\hline
\end{tabular}

under no soil potassium fertilization, from 44.2 to 56.5 ton $\mathrm{ha}^{-1}$ in the first season and from 45.48 to 57.6 ton $\mathrm{ha}^{-1}$ in the second one. Also, from 52.58 to 66.6 ton $\mathrm{ha}^{-1}$ under K-spraying in the first season and from 51.24 to 62.93 ton $^{-1} \mathrm{~h}^{-1}$ in the second one. However, there were low response to boron spraying under potassium fertilization especially with the K-rock. This indicates that potassium sulphate and K-rock contain some boron compounds as impurity. These results agree with those obtained by Osman et al. (2004), Knany et al. (2005) and El-Geddawy et al. (2007).

Table 2 showed that application of $115 \mathrm{~kg} \mathrm{~K}_{2} \mathrm{O} \mathrm{ha}{ }^{-1}$ increased the root yield under no boron fertilization (58.25 and 57.58 ton $\mathrm{ha}^{-1}$ in the first and second seasons, respectively). Wherever, under the boron fertilization, the highest root yield (66.6 and 64.61 ton $\mathrm{ha}^{-1}$ ) were obtained with K-spraying and $115 \mathrm{~kg} \mathrm{~K}_{2} \mathrm{O}$ $\mathrm{ha}^{-1}$ as K-rock treatments in the first and second seasons, respectively. This may be due to the low solubility of K-rock which make slow release of potassium over all the plant ageing. In addition, it may be contain some essential micronutrients which stimulate the plant growth and production. Similar results are obtained by Eid et al. (1997) and Shehata (2006). Table 3 showed that spraying sugar beet plants with boron significantly increased the top yield in both seasons. The increases ranged from $12.9 \%$ to $50.1 \%$ in the first season with an average of $33.6 \%$, the increases in the second season ranged from $25.4 \%$ to $49.4 \%$ with an average of $38.1 \%$. These results are in agreement with those obtained by El-Geddawy et al. (2007) who found that sugar beet top yield increased by $13.83 \%$ and $20.12 \%$ over the control by increasing the levels of boron to 0.5 and $1.0 \mathrm{~kg} \mathrm{fed}^{-1}$. Sugar beet top yield was significantly affected by potassium fertilization. The superior top yield values of 17.64 and 20.26 ton $\mathrm{ha}^{-1}$ in the first season and 15.72 and 21.10 ton $\mathrm{ha}^{-1}$, in the second season without and with boron, respectively. Were obtained with spraying sugar beet with liquid potassium fertilizer. This is due to the potassium spraying which gave the plants its needs of potassium in the critical period and/or the different $\mathrm{pH}$ of potassium solution affected the leave diseases which enhanced the increase of top yield. Similar results were reported by El-Fouly and El-Sayed (1997) and Ismail et al. (2002).

Table 4 showed that boron spraying significantly increased the white sugar yield. The increases values were correlated with potassium treatments and ranged between $3.6 \%$ and $23.2 \%$ in the first season with an average value of $16.2 \%$ and in the second season these increases ranged between $5.9 \%$ and $24.1 \%$ with the an average of $15.2 \%$. The highest values were obtained under no potassium fertilization treatment in both seasons. While, the lowest values were recorded under the fertilization with $115 \mathrm{~kg} \mathrm{~K} \mathrm{~K}_{2} \mathrm{O}$ as $\mathrm{K}$-rock in both seasons.

This is due to the role of boron in translocation of the carbohydrate assimilated in the leaves, thus enhance sugar accumulation in the roots. The lowest response to $\mathrm{B}$ was noticed under K-rock fertilization may be due to K-rock contain some burden boron minerals helpful in plant needs. These results agree with those obtained by Genaidy (1988) who reported that boron fertilization increased sugar \% by $18.3 \%$, El-Geddawy et al. (2007) and El-Hosary et al. (2007).

In respect to the effect of potassium fertilization on sugar yield (Table 4). The highest white sugar yields of 12.05 and 13.68 ton $\mathrm{ha}^{-1}$ in the first season were obtained 

Table 3. Sugar beet top yield (ton ha $\mathrm{h}^{-1}$ ) as affected by boron and potassium fertilization

\begin{tabular}{|c|c|c|c|c|c|c|c|c|}
\hline \multirow{2}{*}{ K treat. } & \multicolumn{2}{|c|}{$\mathbf{1}^{\text {st }}$ season } & \multirow[b]{2}{*}{ Diff. } & \multirow[b]{2}{*}{$\Delta \%$} & \multicolumn{2}{|c|}{$2^{\text {nd }}$ season } & \multirow[b]{2}{*}{ Diff. } & \multirow[b]{2}{*}{$\Delta \%$} \\
\hline & $\begin{array}{l}\text { Without } \\
\text { boron }\end{array}$ & $\begin{array}{c}\text { With } \\
\text { boron }\end{array}$ & & & $\begin{array}{c}\text { Without } \\
\text { boron }\end{array}$ & $\begin{array}{c}\text { With } \\
\text { boron }\end{array}$ & & \\
\hline Without & $10.73 \mathrm{~b}$ & $15.19 \mathrm{c}$ & 4.46 & 29.3 & $10.89 \mathrm{~b}$ & $15.77 \mathrm{~b}$ & 4.87 & 30.8 \\
\hline $115 \mathrm{~K}_{2} \mathrm{SO}_{4}$ & $11.35 \mathrm{~b}$ & $17.14 \mathrm{bc}$ & 5.78 & 33.7 & $11.98 \mathrm{~b}$ & $19.15 \mathrm{ab}$ & 5.98 & 33.2 \\
\hline $57 \mathrm{~K}_{2} \mathrm{SO}_{4}$ & $11.16 \mathrm{~b}$ & $18.91 \mathrm{ab}$ & 7.75 & 40.9 & $11.45 \mathrm{~b}$ & $19.37 \mathrm{a}$ & 7.27 & 37.5 \\
\hline 115 K-rock & $9.60 \mathrm{~b}$ & $19.25 \mathrm{ab}$ & 9.65 & 50.1 & $10.58 \mathrm{~b}$ & $20.95 \mathrm{a}$ & 10.37 & 49.4 \\
\hline 57 K-rock & $11.18 \mathrm{~b}$ & $17.26 \mathrm{abc}$ & 6.07 & 35.1 & $11.57 \mathrm{~b}$ & $78.36 \mathrm{ab}$ & 6.74 & 36.9 \\
\hline K-spray & $17.64 \mathrm{a}$ & $20.25 \mathrm{a}$ & 2.62 & 12.9 & $15.72 \mathrm{a}$ & $21.10 \mathrm{a}$ & 5.38 & 25.4 \\
\hline \multirow[t]{5}{*}{ Means } & 11.92 & 18.00 & 6.05 & 33.6 & 12.02 & 16.99 & 6.48 & 38.1 \\
\hline & \multicolumn{2}{|l|}{ F-test } & \multirow{2}{*}{\multicolumn{2}{|c|}{$\begin{array}{l}1^{\text {st }} \text { season } \\
* *\end{array}$}} & \multicolumn{4}{|c|}{$2^{\text {nd }}$ season } \\
\hline & Boron & & & & \multicolumn{4}{|c|}{$* *$} \\
\hline & \multicolumn{2}{|l|}{$\begin{array}{l}\text { Boron } \\
\text { K-treat. }\end{array}$} & \multicolumn{2}{|c|}{$* *$} & \\
\hline & \multicolumn{2}{|l|}{ B x K } & \multicolumn{2}{|c|}{$* *$} & \multicolumn{4}{|c|}{$* *$} \\
\hline
\end{tabular}

Table 4. White sugar yield (ton $\mathrm{ha}^{-1}$ ) of sugar beet as affected by boron and potassium fertilization

\begin{tabular}{|c|c|c|c|c|c|c|c|c|}
\hline & $\mathbf{1}^{\mathrm{st}} \mathrm{S}$ & SOn & & & $2^{\text {nd }} S$ & ason & & \\
\hline $\mathbf{K}$ & $\begin{array}{c}\text { Without } \\
\text { boron }\end{array}$ & $\begin{array}{c}\text { With } \\
\text { boron }\end{array}$ & Diff. & $\Delta \%$ & $\begin{array}{c}\text { Without } \\
\text { boron }\end{array}$ & $\begin{array}{c}\text { With } \\
\text { boron }\end{array}$ & Diff. & $\Delta \%$ \\
\hline Without & $8.62 \mathrm{c}$ & $11.23 \mathrm{~b}$ & 2.62 & 23.2 & $9.07 \mathrm{c}$ & $11.95 \mathrm{c}$ & 2.88 & 24.1 \\
\hline $115 \mathrm{~K}_{2} \mathrm{SO}_{4}$ & $11.04 \mathrm{ab}$ & $13.06 \mathrm{a}$ & 2.02 & 15.4 & $11.93 \mathrm{ab}$ & $13.90 \mathrm{ab}$ & 1.97 & 14.1 \\
\hline $57 \mathrm{~K}_{2} \mathrm{SO}_{4}$ & $10.37 \mathrm{~b}$ & $13.34 \mathrm{a}$ & 2.98 & 22.2 & $11.28 \mathrm{ab}$ & $12.74 \mathrm{bc}$ & 1.46 & 11.4 \\
\hline 115 K-rock & $12.05 \mathrm{a}$ & $12.48 \mathrm{a}$ & 0.46 & 3.6 & $13.20 \mathrm{a}$ & $14.04 \mathrm{a}$ & 0.84 & 5.9 \\
\hline 57 K-rock & $10.66 \mathrm{~b}$ & $12.46 \mathrm{a}$ & 1.78 & 14.2 & $10.80 \mathrm{~b}$ & $12.74 \mathrm{bc}$ & 1.94 & 15.2 \\
\hline K-spray & $11.09 \mathrm{ab}$ & $13.68 \mathrm{~d}$ & 2.59 & 18.9 & $11.21 \mathrm{ab}$ & $14.23 \mathrm{a}$ & 3.02 & 21.2 \\
\hline Means & 10.63 & 12.70 & 2.06 & 16.2 & 12.05 & 13.25 & 2.02 & 15.2 \\
\hline & F-test & & & eason & & & & \\
\hline & Boron & & & $*$ & & & & \\
\hline & K-treat. & & & $* *$ & & & & \\
\hline & $\mathrm{B} \times \mathrm{K}$ & & & * & & & & \\
\hline
\end{tabular}

with $115 \mathrm{~kg} \mathrm{~K} \mathrm{~K}_{2} \mathrm{O}$ as K-rock under no boron fertilization and with potassium spraying under the boron fertilization, respectively. In the second season the highest values of 13.2 and 14.23 ton ha $^{-1}$ were obtained with previous treatments in the first season. Spraying potassium was the superior K-treatment on sugar yield. These results agree with those obtained by Eid et al. (1997), Ismail et al. (2002) and Shehata (2006).

Table 5 showed that, there was a clear relationship between boron fertilization and sodium $\%, \alpha$ amino nitrogen $\%$ and quality $\%$ in both seasons, since boron fertilization increased sodium \% from 1.88 and $1.89 \%$ to 1.92 and $1.94 \%$ in the first and second seasons, respectively. On the other hand, boron fertilization led to decrease $\alpha$ amino nitrogen from 2.2 and $2.27 \%$ to 2.01 and $2.14 \%$ in the first and second seasons, respectively. Sodium concentration and $\alpha$ amino nitrogen concentration in the juice reflected on juice quality $\%$, where boron fertilization increased juice quality from 86.04 and $85.78 \%$ to 86.37 and $86.25 \%$ in the first and second seasons, respectively. This may be due to the role of boron in nitrogen and sodium assimilation. Similar results were reported by Abd ElGawad et al. (2004) and El-Hosary et al. (2007).

In respect to the effect of potassium fertilization on potassium, $\alpha$ amino nitrogen and quality $\%$ of sugar beet juice (Table5), it is clear that soil application of potassium sources led to a decrease potassium concentration in the juice in both season compared to unfertilized with potassium control and the spraying treatment. This may be due to the competition between $\mathrm{Na}^{+}$and $\mathrm{K}^{+}$on the root surface. In general potassium fertilization led to decrease of $\alpha$ amino nitrogen especially under no boron fertilization. This may be due to the balanced between the nitrogen and potassium and increasing $\mathrm{K}$ increased $\mathrm{N}$ assimilation, therefore decreased $\alpha$ amino $\mathrm{N}$. All the potassium sources and levels studied led to increase sugar beet juice quality comparing with unfertilized with potassium control. 
These results agree with those obtained by Voth (1978), Genaidy (1988) and Zein et al. (2005) who found that $57 \mathrm{~kg} \mathrm{~K}_{2} \mathrm{O}$ ha $^{-1}$ gave the highest values of purity $\%$.

Table 6 showed that boron fertilization led to increase nitrogen in sugar beet leaves from 2.31 and $2.32 \%$ in the first and second seasons, respectively to 2.38 and $2.40 \%$. Phosphorus also was increased from 0.65 and $0.68 \%$ to 0.67 and $0.69 \%$ in the first and second seasons, respectively due to boron fertilization. The increases in the nitrogen and phosphorus concentration of sugar beet leaves may be due to the balanced in the plant nutrients due to boron, to the role of boron in growth activity and protein production. These results are harmony accepted to the obtained by Domska (1996) and Abd El-Gawad et al. (2004) who reported that boron fertilization gave the highest $\mathrm{N}, \mathrm{Na}$, $\mathrm{K} \%$ values. No clear effects of boron fertilization on the available nitrogen in the soil after the harvesting. However, the boron fertilization led to decrease the available phosphorus in the soil after harvesting. This may be due to boron fertilization stimulate sugar beet growth which absorbed more available phosphorus.

Potassium fertilization in general increased nitrogen percent in the sugar beet leaves (Table 6). The highest value of $2.63 \%$ was observed in both seasons with potassium spraying treatment. Phosphorus percentage clearly increased due to potassium fertilization in both seasons. The highest values $(0.69$ and $0.71 \%)$ were obtained with $115 \mathrm{~kg} \mathrm{~K}_{2} \mathrm{O} \mathrm{ha}^{-1}$ in the first and second season, respectively followed by 0.66 and $0.70 \%$ with potassium spraying in the first and second seasons, respectively. This may be due to the balanced manuring which led to increasing of nutrients concentration in the leaves. Similar results were reported by Lielah and Taha (1992) and Shehata (2006).

Available nitrogen was decreased in the soil after harvesting due to soil potassium fertilization in both seasons. No clear effect due to potassium spraying on the available nitrogen in the soil after harvesting. The higher potassium rates had the lowest available nitrogen values. This may be due to potassium compounds helpful in leaching some nitrogen from the soil particle surfaces. No clear relation between available-P in the soil after harvesting and potassium fertilization.

Table 7 showed that boron fertilization led to increase $\mathrm{K} \%$ in the root from 5.03 and 5.05 to 5.06 in the first and second seasons, respectively. On the other hand, potassium concentration in the sugar beet leaves were decreased from $5.4 \%$ and $5.23 \%$ to $5.09 \%$ and $4.98 \%$ due to boron fertilization in the first and second seasons, respectively. Also, boron fertilization led to decrease the available potassium in the soil after the harvesting. The decreases were from 506.9 and $543 \mathrm{mg}$ $\mathrm{kg}^{-1}$ to 455.7 and $486.8 \mathrm{mg} \mathrm{kg}^{-1}$ in the first and second seasons, respectively.

The decreases in $\mathrm{K}$ in the leaves and available- $\mathrm{K}$ in the soil may be due to the increases in the plant growth with boron fertilization which causes K-dilution effect and in the soil increasing the K-absorption causes high K-removal from the soil. These results are agree with those obtained by Abd El-Gawad et al. (2004), ElHosary et al. (2007) and El-Geddawy et al. (2007).

\section{Table 5. Sodium, $\alpha$ amino-N and quality of sugar beet juice as affected by boron and potassium fertilization}

\begin{tabular}{|c|c|c|c|c|c|c|c|}
\hline \multirow{2}{*}{ Boron treat. } & \multirow{2}{*}{ K treat. } & \multicolumn{2}{|c|}{ Sodium \% } & \multicolumn{2}{|c|}{$\alpha \operatorname{amino} \mathbf{N} \%$} & \multicolumn{2}{|c|}{ Quality \% } \\
\hline & & $1^{\text {st }}$ season & $2^{\text {nd }}$ season & $1^{\text {st }}$ season & $2^{\text {nd }}$ season & $1^{\text {st }}$ season & $2^{\text {nd }}$ season \\
\hline \multirow[t]{7}{*}{ Without } & Without & 1.92 & 1.94 & 2.73 & 2.64 & 85.10 & 85.36 \\
\hline & $115 \mathrm{~K}_{2} \mathrm{SO}_{4}$ & 1.84 & 1.88 & 1.72 & 1.83 & 86.40 & 86.72 \\
\hline & $57 \mathrm{~K}_{2} \mathrm{SO}_{4}$ & 1.89 & 1.91 & 2.06 & 2.13 & 86.53 & 86.61 \\
\hline & 115 K-rock & 1.86 & 1.84 & 2.15 & 2.22 & 85.80 & 85.95 \\
\hline & 57 K-rock & 1.94 & 1.90 & 2.19 & 2.31 & 84.60 & 84.50 \\
\hline & K-spray & 1.83 & 1.8 & 2.33 & 2.46 & 87.80 & 85.56 \\
\hline & Means & 1.88 & 1.89 & 2.20 & 2.27 & 86.04 & 85.78 \\
\hline \multirow[t]{7}{*}{ With } & Without & 1.93 & 1.95 & 2.05 & 2.12 & 86.70 & 86.82 \\
\hline & $115 \mathrm{~K}_{2} \mathrm{SO}_{4}$ & 1.92 & 1.94 & 1.89 & 2.06 & 86.57 & 86.61 \\
\hline & $57 \mathrm{~K}_{2} \mathrm{SO}_{4}$ & 1.83 & 1.88 & 2.05 & 2.18 & 86.87 & 86.77 \\
\hline & 115 K-rock & 1.86 & 1.91 & 2.01 & 2.11 & 86.03 & 85.99 \\
\hline & 57 K-rock & 1.96 & 1.98 & 2.02 & 2.15 & 86.04 & 85.86 \\
\hline & K-spray & 2.00 & 1.99 & 2.04 & 2.20 & 85.63 & 85.46 \\
\hline & Means & 1.92 & 1.94 & 2.01 & 2.14 & 86.37 & 86.25 \\
\hline
\end{tabular}


Table 6. Nitrogen, $P$ in sugar beet leaves, available $N$ and $P$ in the soil after harvesting as affected by boron and potassium fertilization

\begin{tabular}{|c|c|c|c|c|c|c|c|c|c|}
\hline \multirow{2}{*}{ Boron treat. } & \multirow{2}{*}{ K treat. } & \multicolumn{2}{|c|}{$\begin{array}{c}\mathrm{N} \% \\
\text { in leaves } \\
\end{array}$} & \multicolumn{2}{|c|}{$\begin{array}{c}\mathrm{P} \% \\
\text { in leaves } \\
\end{array}$} & \multicolumn{2}{|c|}{$\begin{array}{c}\text { Available } \mathbf{N} \text { in soil } \\
(\mathbf{p p m})\end{array}$} & \multicolumn{2}{|c|}{$\begin{array}{c}\text { Available } P \text { in soil } \\
(\mathbf{p p m})\end{array}$} \\
\hline & & $1^{\text {st }}$ season & $\begin{array}{c}2^{\text {nd }} \\
\text { season } \\
\end{array}$ & $1^{\text {st }}$ season & $\begin{array}{c}2^{\text {nd }} \\
\text { season }\end{array}$ & $1^{\text {st }}$ season & $\begin{array}{c}2^{\text {nd }} \\
\text { season }\end{array}$ & $1^{\text {st }}$ season & $\begin{array}{c}2^{\text {nd }} \\
\text { season }\end{array}$ \\
\hline \multirow[t]{6}{*}{ Without } & Without & 2.10 & 2.08 & 0.60 & 0.62 & 26.75 & 27.00 & 28.00 & 19.50 \\
\hline & $115 \mathrm{~K}_{2} \mathrm{SO}_{4}$ & 2.45 & 2.48 & 0.71 & 0.74 & 17.50 & 17.50 & 22.33 & 23.00 \\
\hline & $57 \mathrm{~K}_{2} \mathrm{SO}_{4}$ & 2.33 & 2.39 & 0.62 & 0.66 & $19.9 * 0$ & 21.25 & 17.33 & 19.83 \\
\hline & 115 K-rock & 2.22 & 2.26 & 0.65 & 0.68 & 16.90 & 17.50 & 27.00 & 30.00 \\
\hline & 57 K-rock & 2.16 & 2.19 & 0.60 & 0.61 & 19.25 & 21.00 & 19.50 & 21.00 \\
\hline & K-spray & 2.57 & 2.54 & 0.72 & 0.75 & 26.00 & 27.17 & 23.00 & 23.00 \\
\hline \multicolumn{2}{|c|}{ Means } & 2.31 & 2.32 & 0.65 & 0.68 & 21.05 & 21.90 & 22.84 & 22.72 \\
\hline \multirow[t]{7}{*}{ With } & Without & 1.93 & 2.06 & 0.63 & 0.67 & 25.67 & 27.33 & 27.00 & 22.00 \\
\hline & $115 \mathrm{~K}_{2} \mathrm{SO}_{4}$ & 2.34 & 2.40 & 0.65 & 0.64 & 17.50 & 19.75 & 23.33 & 24.30 \\
\hline & $57 \mathrm{~K}_{2} \mathrm{SO}_{4}$ & 2.57 & 2.49 & 0.67 & 0.70 & 19.67 & 22.17 & 19.33 & 21.00 \\
\hline & 115 K-rock & 2.39 & 2.42 & 0.72 & 0.73 & 22.17 & 19.75 & 18.00 & 22.33 \\
\hline & 57 K-rock & 2.34 & 2.33 & 0.72 & 0.72 & 21.00 & 21.00 & 16.00 & 19.50 \\
\hline & K-spray & 2.68 & 2.71 & 0.60 & 0.65 & 25.67 & 26.23 & 18.33 & 22.33 \\
\hline & Ieans & 2.38 & 2.40 & 0.67 & 0.69 & 21.94 & 22.71 & 20.33 & 21.91 \\
\hline
\end{tabular}

Table 7. Potassium in root, $K$ in leaves and available-K in the soil after harvesting $\mathrm{mg} \mathrm{kg}^{-1}$ as affected by boron and potassium fertilization

\begin{tabular}{|c|c|c|c|c|c|c|c|}
\hline \multirow{2}{*}{ Boron treat. } & \multirow[b]{2}{*}{ K treat. } & \multicolumn{2}{|c|}{$\mathrm{K} \%$ in root } & \multicolumn{2}{|c|}{$\mathrm{K} \%$ in leaves } & \multicolumn{2}{|c|}{$K$ in soil (ppm) } \\
\hline & & $1^{\text {st }}$ season & $2^{\text {nd }}$ season & $1^{\text {st }}$ season & $2^{\text {nd }}$ season & $1^{\text {st }}$ season & $2^{\text {nd }}$ season \\
\hline \multirow[t]{7}{*}{ Without } & Without & 4.85 & 4.90 & 4.89 & 4.62 & 449.80 & 462.20 \\
\hline & $115 \mathrm{~K}_{2} \mathrm{SO}_{4}$ & 5.18 & 5.04 & 6.13 & 5.93 & 575.7 & 590.39 \\
\hline & $57 \mathrm{~K}_{2} \mathrm{SO}_{4}$ & 4.86 & 5.02 & 5.49 & 5.36 & 540.90 & 554.72 \\
\hline & 115 K-rock & 5.24 & 5.21 & 5.49 & 5.22 & 456.57 & 599.65 \\
\hline & 57 K-rock & 5.06 & 5.12 & 5.07 & 4.98 & 512.32 & 583.16 \\
\hline & K-spray & 5.04 & 5.05 & 5.42 & 5.28 & 506.33 & 467.90 \\
\hline & Means & 5.03 & 5.05 & 5.40 & 5.23 & 506.87 & 543.00 \\
\hline \multirow[t]{7}{*}{ With } & Without & 4.83 & 4.91 & 4.39 & 4.42 & 440.90 & 432.8 \\
\hline & $115 \mathrm{~K}_{2} \mathrm{SO}_{4}$ & 5.20 & 5.13 & 5.66 & 5.46 & 484.70 & 529.70 \\
\hline & $57 \mathrm{~K}_{2} \mathrm{SO}_{4}$ & 4.98 & 4.94 & 4.97 & 4.92 & 446.85 & 438.22 \\
\hline & 115 K-rock & 5.28 & 5.20 & 5.30 & 5.26 & 462.55 & 579.36 \\
\hline & 57 K-rock & 5.01 & 5.07 & 5.09 & 4.73 & 454.00 & 468.18 \\
\hline & K-spray & 5.03 & 5.10 & 5.15 & 5.08 & 445.70 & 472.76 \\
\hline & Means & 5.06 & 5.06 & 5.09 & 4.98 & 455.78 & 486.83 \\
\hline
\end{tabular}

Potassium fertilization increased $\mathrm{K}$ in the roots and in the leaves in both seasons (Table 7). The highest $\mathrm{K}$ values in the root and the leaves were correlated with the higher potassium levels. Available $\mathrm{K} \mathrm{mg} \mathrm{kg}^{-1}$ in the soil was increased with the soil application of the potassium fertilizer. The highest available potassium values in the soil were attributed to the higher levels of the fertilizers added to the soil. Similar results were obtained by Morsy and Taha (1986), Ghaly et al. (1984) and Abu El-Fotoh et al. (2000).

\section{REFERENCES}

Abd El-Gawad, A.M.; S.A.H. Allam; L.M.A. Saif and A.M.H. Osman (2004). Effect of some micronutrients on yield and quality of sugar beet (Beta vulgaris L.). II. juice quality and chemical compositions. Egypt. J. Agric. Res. 82: 681-701.

Abd El-Hadi, A.H.; A.M.A. Aly; A.A. Attiat; M.A. Zidan and F. Zahran (2002). Response of sugar beet to various forms and rates of nitrogenous fertilizer. Egypt J. Soil Sci. 42: 643-658. 
Abu El-Fotoh, H.G.; A.A. Abd El-Magid and R.E. Knany (2000). Effects of biofertilization on sugar beet yield, quality and optimization of chemical fertilizers. The Ninth Conference of agronomy. Minufiya Univ. September. 2-3, 2000 pp. 561-567.

Black, C.A.; D.D. Evans; J.L. White; L.E. Ensuminger and F.E. Clark (1965). Methods of soil Analysis. Am. Soc. Agron. Inc. Publ., Madison Wisconsin, U.S.A.

Domska, D. (1996). Yield and quality of sugar beet after foliar feeding with nitrogen, magnesium, boron and copper. Polish J. Food Nut. Sci. 5: 23-31.

Eid, E.T.; M.H. Abdel-Aal; M.S. Ismail and M.M. Wassel (1997). Response of Egyptian cotton to $\mathrm{K}$ and micronutrient application. Proc. FAO-IRCRNC; Joint meeting of working groups (cotton nutrition, growth regulators) Cairo Egypt, pp. 189-190.

El-Fouly, M.M. and A.A. El-Sayed (1997). Foliar fertilization an environmentally friendly application of fertilizers. Dahlia Greidenger International Symposium of Fertilization an Environment. pp. 346-358.

El-Geddawy, I.H.; A.A. El-Hosary; A.M.M. Saad and B.S. Ibrahim (2007). Effect of boron and molybdenum on growth and yield of some sugar beet varieties. Egypt. J. Agric. Res. 85: 1355-1366.

El-Hosary, A.A.; A.M.M. Saad; I.H. El-Geddawy and B.S. Ibrahim (2007). Effect of boron and molybdenum on chemical constitutes and quality of some sugar beet varieties. Egypt. J. Agric. Res. 85: 1335-1347.

Genaidy, S.A. (1988). Role of potassium, boron and zinc; fertilization on yield and quality of sugar beet growth on northern Delta Soils. Alex. Sci. Exch. 9: 25-34.

Ghaly, S.; I. Abdel Aziz and M. Moursy (1984). Response of sugar beet to potassium and boron fertilization in Egyptian Soil. Agric. Res. Rev. 62: 273-279.

Gomez, K.A. and A.A. Gomez (1984). Statistical procedures for Agricultural Research. John Willey and Sons. Inc. York.

Ismail, A.M.A.; Kh.A. Abushady and S.M. Allam (2002). Response of some sugar beet varieties to methods of potassium application. Egypt. J. Appl. Sci., 17: 86-101.

Jackson, M.L. (1958). Soil Chemical Analysis. Prentice-Hall, Incl. Englewood Cliffs, New York, USA.
Knany, R.E.; A.S.M. El-Saady; R.H. Atia and N.M.M. Awad (2005). Response of sugar beet to different seedling methods, phosphorus fertilizer management and spraying with some nutrients. J. Agric. Sci. Mansoura Univ. 30: 8246-8258

Lielah, A.A. and A.A. Taha (1992). Effect of nitrogen, phosphorus and potassium fertilizer on growth and yield of sugar beet. J. Agric. Sci. Mansoura Univ., 17: 25412548.

Morsy, M.A. and E.M. Taha (1986). Effect of B and Mn and their combination on sugar beet under El-Mini condition. 2- Concentration and uptake of N, P, K, B and Mn. Ann. Agric. Sci. Ain Shams Univ. 31: 1241-1259.

Nafei, A.I. (2004). Effect of nitrogen and boron fertilization levels on yield and quality of sugar beet grown in upper Egypt. J. Appl. Sci. 19: 48-57.

Osman, A.M.H.; G.S. El-Sayed and A.I. Nafei (2004). Effect of foliar application date of boron and bioconstuituents yeast extraction on yield and quality of sugar beet. Egypt. J. Appl. Sci. 19: 76-98.

Osman, A.M.H.; G.S. El-Sayed; M.S.H. Osman and K.S. ElSoheir (2003). Soil application of some microelements with relation to yield and quality of sugar beet varieties. Ann. of Agric. Sci. Moshtohor, Zagazig Univ. 41: 11351152.

Osman, M.S.H. (2005). Effect of potassium and magnesium on yield and quality of two sugar beet varieties. Egypt. J. Agric. Res., 83: 215-228.

Saif, Laila, M. (2000). Stepwise regression and path coefficient analysis for some sugar beet characters under levels of boron and nitrogen fertilization. proc. $9^{\text {th }}$ conf. Agron. Minufya Univ. 569-581.

Shehata, Sh.M. (2006). Study on some K-rich sediments present in the Eastern Desert of Egypt. Egypt. J. Agric. Res. 84: 1017-1024.

Voth, R.D. (1978). Effect of boron and manganese fertilizer on yield and quality and nutrition of sugar beet. C.F. Field Crops Abstracts. Vol. 34 No. 2.

Zein, F.I.; N.I. Talha; A.M. Abu El-Khir and Hamida A. ElSanafawy (2005). Effect of K fertilization on recovering drought hazards on sugar beet cultivars at late season. J. Agric. Sci. Mansoura Univ., 30: 6357-6370. 


\section{الملخص العربي}

\section{دراسة مقارنة بين مصادر الأسمدة البوتاسية فى وجود البورون على محصول بنجر السكر وجودة العصير}

رمضان اسماعيل كنافن، عاطف صبحى محمود السعدى، رجب حجازى عطية، نبيل مرسى عوض

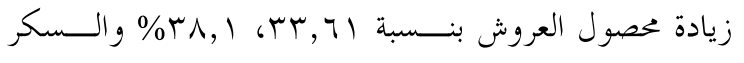

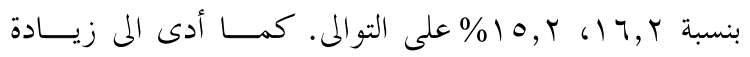

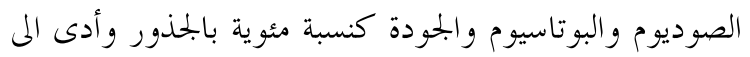

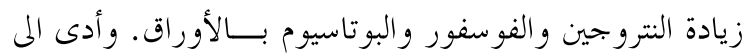

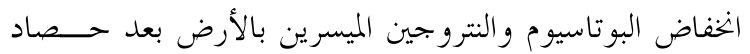

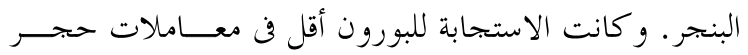

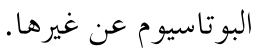

- أدى التسميد بالبوتاسيوم بوجه عام إلى زيادة محصول الجـــــور والعروش وكانت أعلى القيم مع الرش بالبوتاسيوم في حالــــة

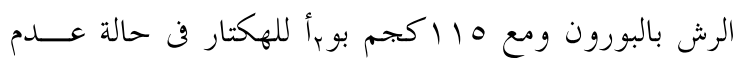

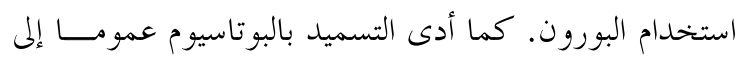
زيادة تركيز البوتاسيوم ومحصول السكر بالجذور والنسبة المئوية للجودة وزيادة تركيز البوتاسيوم والنتروجين في الأوراق. كما

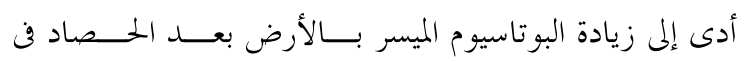

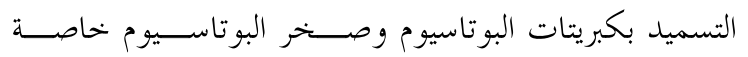
المستوى 110 النتروجين الميسر بالأرض بعد الحصاد.

ومن النتائج يمكن استخدام صخر البوتاسيوم والرش بالبوتاسيوم

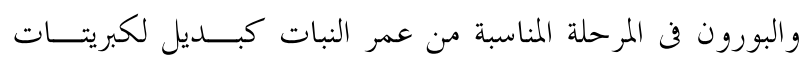

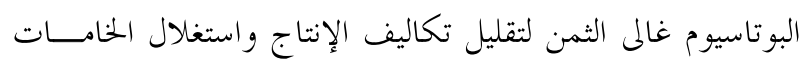
الموجودة بالصحراء الشرقية لمصر كمــصدر للبوتاســيوم بــــيلا لالاستير اد.
يهدف البحث الى دراسة إمكانية استخدام الــصخور الغنيــة بالبوتاسيوم من صحراء مصر الشرقية والرش بمحاليل البوتاســيوم فن المراحل الحرجة في وجود البورون كبدائل للأسمدة البوتاسية المعتادة غالية الثمن وأثرها على انتاجية البنجر وجودة عصيره. أجريت بتربتان حقليتان بمزرعة محطة البحوث الزراعية بـسـخا

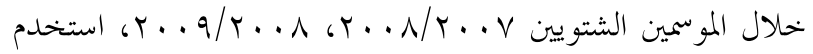
تصميم القطع المنشقة فن تنفيذ التجارب في أربع مكررات. شـــلت القطع الرئيسية بمعاملتين للبورون (1)بدون رش بــالبورون و (r)

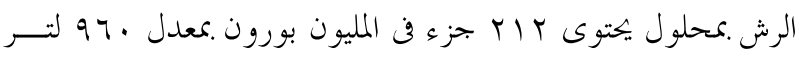

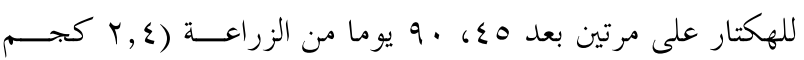

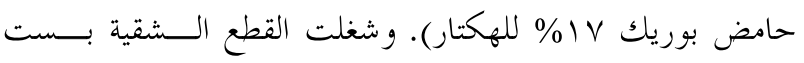
معاملات للبوتاسيوم هى (1) بدون بوتاسيوم و(r) إضـــافة 110

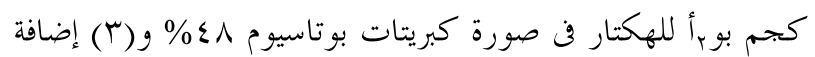

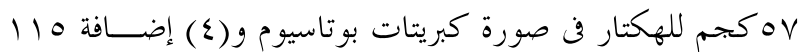
كجم بو أ للهكتار في صورة صخر البوتاسيوم V,0\% بوبأ و (0) إضافة Vo كجم بو أ للهكتار في صورة صــخر البوتاســيوم و (T)

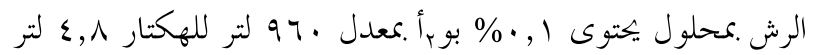

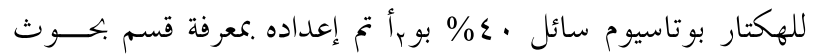
خصوبة الاراضى وتغذية النبات بسخا بإذابة مصدر للبوتاســيوم في محلول يحتوى حامض الفولفيك) ويمكن تلخيص النتائج في الأتى: - أدى الرش بالبورون إلى زيادة محصول الجذور بنسسبة 70,10،

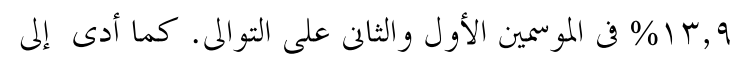


